\title{
Deposisi ZnO Doping Ag pada Substrat Alumunium Foil untuk Degradasi Methylene Blue
}

\author{
Sheilla Rully Anggita \\ Jurusan Fisika, Fakultas Sains dan Teknologi, UIN Walisongo Semarang, Indonesia, 50185 \\ Email: sheillarully@walisongo.ac.id
}

Diterima (Tanggal Bulan Tahun), Direvisi (Tanggal Bulan Tahun)

\begin{abstract}
This research has successfully deposited ZnO: Ag on aluminum foil substrates with variations in deposition temperature. The purpose of this study was to obtain the surface morphology of ZnO:Ag on aluminum foil substrates with variations in deposition temperature and obtain optimization of the photocatalytic activity of ZnO: Ag in degrading Methylene Blue dyes. ZnO:Ag deposition on the aluminum foil substrate was carried out by the sol-gel method and spray coating deposition technique. Surface morphology characterization and photocatalytic activity with SEM and with UV-Vis. The surface morphology results obtained from ZnO:Ag on aluminum foil substrate with deposition temperatures of $250^{\circ} \mathrm{C}, 300^{\circ} \mathrm{C}, 350^{\circ} \mathrm{C}$, and $400^{\circ} \mathrm{C}$ are the forms of ganglia with indications as $\mathrm{ZnO}$ and Ag grains attached to $\mathrm{ZnO}$. Obtained surface area and roughness level ZnO:Ag decreases with an increase in temperature from $250{ }^{\circ} \mathrm{C}-300^{\circ} \mathrm{C}$, and surface area and roughness increases at $350{ }^{\circ} \mathrm{C}-400{ }^{\circ} \mathrm{C}$. The highest level of roughness is found in the $\mathrm{ZnO}$ layer: Ag temperature $400^{\circ} \mathrm{C}$. The most optimum photocatalytic activity is indicated by the largest percentage of degradation. The highest percentage of degradation is shown by the ZnO: Ag layer with a temperature of $350{ }^{\circ} \mathrm{C}$ of $87.33 \%$. This is due to the modification of silver at low temperatures which is $<400{ }^{\circ} \mathrm{C}$ effective for photocatalytic activity.
\end{abstract}

Keywords: aluminum foil, degradation, deposition, methylene blue, $\mathrm{ZnO}$ : Ag,.

Abstrak. Penelitian ini telah berhasil mendeposisikan $\mathrm{ZnO}: \mathrm{Ag}$ pada substrat alumunium foil dengan variasi suhu deposisi. Tujuan dari penelitian ini adalah untuk mendapatkan morfologi permukaan ZnO:Ag pada substrat alumunium foil dengan variasi suhu deposisi dan mendapatkan optimasi aktivitas fotokatalitik $\mathrm{ZnO}: \mathrm{Ag}$ dalam mendegradasi zat warna methylene blue. Deposisi lapisan $\mathrm{ZnO}: \mathrm{Ag}$ pada substrat alumunium foil dilakukan dengan metode sol-gel dan teknik pendeposisian spray coating. Pengujian morfologi permukaan dengan uji SEM dan aktivitas fotokatalitik dengan uji UV-Vis. Didapatkan hasil morfologi permukaan dari ZnO:Ag pada substrat alumunium foil dengan suhu deposisi $250^{\circ} \mathrm{C}, 300^{\circ} \mathrm{C}, 350^{\circ} \mathrm{C}$, dan $400^{\circ} \mathrm{C}$ adalah bentuk ganglia dengan indikasi sebagai $\mathrm{ZnO}$ dan bulir Ag yang menempel pada $\mathrm{ZnO}$. Didapatkan luas permukaan dan tingkat kekasaran $\mathrm{ZnO}: \mathrm{Ag}$ menurun dengan adanya peningkatan suhu dari $250^{\circ} \mathrm{C}-300^{\circ} \mathrm{C}$, dan kembali meningkat pada suhu $350^{\circ} \mathrm{C}-400^{\circ} \mathrm{C}$. Tingkat kekasaran terbesar yaitu terdapat pada lapisan $\mathrm{ZnO}: \mathrm{Ag}$ suhu $400^{\circ} \mathrm{C}$. Aktivitas fotokatalitik paling optimum ditunjukkan dengan prosentase degradasi terbesar. Prosentase degradasi terbesar ditunjukkan oleh lapisan $\mathrm{ZnO}: \mathrm{Ag}$ dengan suhu $350^{\circ} \mathrm{C}$ sebesar $87,33 \%$. Hal ini disebabkan karena modifikasi perak pada suhu rendah yaitu $<400^{\circ} \mathrm{C}$ efektif untuk aktifitas fotokatalitik.

Kata kunci: alumunium foil, degradasi, deposisi, methylene blue, $\mathrm{ZnO}$ :Ag.

\section{PENDAHULUAN}

Berkurangnya jumlah air bersih saat ini sangatlah mengkhawatirkan. Penurunan kualitas ataupun kuantitas air bersih ini diakibatkan oleh dua alasan utama, yaitu peningkatan populasi yang cepat dan peningkatan jumlah industri. Peningkatan jumlah industri mengakibatkan meningkatnya pula jumlah limbah yang mencemari air di lingkungan sekitar. Sebagai contoh meningkatnya industri tekstil, hal ini akan berkontribusi terhadap peningkatan polusi air akibat zat warna tekstil yang terlarut dalam air [1].

Untuk mengatasi pencemaran air tersebut, maka dibutuhkan suatu teknologi yang murah, efisien dan sangat mudah dilakukan. Teknologi tersebut adalah pemanfaatan fotokatalis sebagai pendegradasi polutan menggunakan 
bantuan cahaya. Fotokatalis merupakan metode penjernihan air yang lebih menjanjikan dibandingkan dengan metode konvensional lainnya [2]. Proses fotokatalis ini memanfaatkan prinsip semikonduktor dengan besarnya energi celah pita yang dimiliki semikonduktor. Proses fotokatalis terjadi apabila material semikonduktor yang memiliki energi celah pita tertentu diberikan energi dari luar yang sesuai seperti energi cahaya, maka akan terjadi transformasi kimia sehingga mengubah senyawa anorganik dan senyawa organik yang menempel di material tersebut menjadi air dan karbon dioksida [3].

Zinc Oxide $(\mathrm{ZnO})$ merupakan salah satu material fotokatalis yang memiliki kemampuan stabilitas termal dan stabilitas kimia yang baik pada suhu kamar. $\mathrm{ZnO}$ menarik banyak perhatian peneliti karena $\mathrm{ZnO}$ memiliki banyak keuntungan untuk berbagai kepentingan. $\mathrm{ZnO}$ memiliki banyak kelebihan dalam berbagai aplikasi terutama dalam aplikasi fotokatalis [4]. Hal ini dikarenakan $\mathrm{ZnO}$ merupakan semikonduktor dengan tipe-n yang memiliki energi celah pita yang cukup besar yaitu 3,37 $\mathrm{eV}$ dan energi ikat sebesar $60 \mathrm{MeV}$ [5].

Menyisipkan nanostruktur logam transisi pada semikonduktor atau yang dikenal sebagai doping merupakan salah satu metode yang efektif untuk mengefisienkan fungsi semikonduktor. Hal tersebut efektif untuk menyesuaikan tingkat energi semikonduktor tersebut. Salah satu cara untuk meningkatkan sifat fisik maupun sifat optis dari bahan semikonduktor tersebut dengan meningkatkan konsentrasi doping logam transisi sehingga tingkat energinya pun akan berubah [6]. Manfaat doping logam transisi yang lain adalah meningkatkan jumlah elektron yang terjebak agar menghambat proses rekombinasi electronhole selama radiasi. Dengan adanya penurunan proses rekombinasi ini dapat meningkatkan aktivitas fotokatalitiknya [7].

Salah satu jenis logam transisi tersebut adalah perak (Ag). Penelitian sebelumnya telah dilakukan deposisi $\mathrm{ZnO}$ dengan didoping Perak (Ag) dapat meningkatkan efisiensi fotokatalitik [8]. Ion perak $(\mathrm{Ag})$ sangat menarik perhatian karena aktivitas fotokatalitik dan antibacterial yang luar biasa. Penelitian yang telah dilakukan dengan doping Ag dapat meningkatkan aktifitas fotokatalitiknya di bawah penyinaran sinar tampak dengan memisahkan electron hole [9].

Penelitian $\mathrm{ZnO}$ dideposisikan diberbagai substrat telah didapatkan berbagai bentuk morfologi. Deposisi $\mathrm{ZnO}$ doping Ag pada substrat kaca telah dilakukan dengan metode sol-gel didapatkan morfologi permukaan berupa fase ganglia dengan bulir $\mathrm{Ag}$ yang menempel di permukaan dengan ukuran bulir bervariasi 76,5 - 252,5 $\mathrm{nm}$. Penelitian $\mathrm{ZnO}$ doping Ag dengan variasi suhu annealing didapatkan struktur Kristal berupa hexagonal wurtzite pada suhu $250^{\circ}-300^{\circ} \mathrm{C}$, namun dengan suhu $>300^{\circ}$ terbentuk struktur amorf [10].

Selain substrat kaca, deposisi $\mathrm{ZnO}$ dengan substrat aluminium foil telah dilakukan banyak penelitian, diantaranya didapatkan morfologi $\mathrm{ZnO}$ nanosized coral reef, $\mathrm{ZnO}$ nanosized particle yang berpori, dan nanorods. Deposisi $\mathrm{ZnO}$ di atas substrat aluminium foil telah dilakukan melalui penguapan serbuk logam zinc dengan teknik penguapan panas vakum non-katalitik pada suhu tinggi, didapatkan morfologi $\mathrm{ZnO}$ nano-sized coral reef [11]. Selain itu, penelitian lain telah berhasil mendeposisikan $\mathrm{ZnO}$ di atas substrat aluminium foil dengan metode sol-gel terbentuk partikel ukuran nano dengan diameter rata-rata $52 \mathrm{~nm}$, dimana dapat mendegradasi polutan organik[12].

Penelitian Jabeen (2017) juga telah berhasil mendeposisikan $\mathrm{ZnO}$ di atas substrat aluminium foil didapatkan morfologi nanorods. Penelitian juga telah diselidiki dengan substrat konduktor dapat meningkatkan kualitas permukaan berpori. Permukaan yang diinginkan dapat meningkatkan sensitivitas secara krusial. Penginderaan etanol juga dapat ditingkatkan dengan bantuan memodifikasi substrat konduktor yang meningkatkan kualitas nanorod $\mathrm{ZnO}$ [13].

Penelitian ini dilakukan studi deposisilapisan Zinc Oksida doping perak (ZnO:Ag) pada substrat aluminium foil dengan metode sol-gelmenggunakan teknik thermal spray coating untuk degradasi methylene blue. Selanjutnya akan dipelajari pengaruh suhu deposisi terhadap morfologi dari $\mathrm{ZnO}$ :Ag yang 
dideposisikan pada substrat aluminium foil dan pengaruhnya terhadap degradasi zat warna limbah batik methylene blue.

\section{METODE PENELITIAN}

Penelitian yang akan dilakukan secara umum dibagi menjadi 3 tahap, yaitu: proses pembuatan sol-gel $\mathrm{ZnO}$ dengan pencampuran doping Ag dengan konsentrasi 4\%, proses pendeposisian $\mathrm{ZnO}: \mathrm{Ag}$ pada alumunium foil dengan variasi suhu deposisi, dan pengujian aktifitas fotokatalitik dengan pemaparan sinar uv dalam wadah kaca yang sudah terlapisi aluminium foil dengan lapisan $\mathrm{ZnO}: \mathrm{Ag}$.

Pembuatan sol-gel $\mathrm{ZnO}: \mathrm{Ag}$ adalah membuat sol-gel $\mathrm{ZnO}$ kemudian baru didapatkan sol-gel ZnO:Ag. Pembuatan sol-gel $\mathrm{ZnO}$ adalah dengan mealarutkan Zinc acetate dehydrate $\left(\mathrm{Zn}\left(\mathrm{COOCH}_{3}\right)_{2} . \quad 2 \mathrm{H}_{2} \mathrm{O}\right.$ kedalam isopropanol $\left(\left(\mathrm{CH}_{3}\right)_{2} \mathrm{CHOH}\right)$ diaduk dengan magnetic stirrer dan diteteskan monoethanolamine (MEA: $\mathrm{HOCH}_{2} \mathrm{CH}_{2} \mathrm{NH}_{2}$ ) dengan jumlah volume sesuai dengan konsentrasinya yaitu $0,3 \mathrm{M}$ dan perbandingan molar dari MEA dan ZnAc yaitu 1:1. Kemudian larutan diaduk dan dipanaskan pada temperatur $70^{\circ} \mathrm{C}$ selama 30 menit hingga didapatkan solgel $\mathrm{ZnO}$ yang jernih dan homogen dengan tujuan menguraikan senyawa garam asetat menjadi oksida. Untuk mendapatkan sol-gel $\mathrm{ZnO}$ :Ag maka prosedurnya adalah sol-gel $\mathrm{ZnO}$ yang masih diaduk pada temperature $70{ }^{\circ} \mathrm{C}$ kemudian larutan ditambahkan bubuk Silver Nitrate $(\mathrm{Ag}(\mathrm{NO} 3))$ sebagai doping dengan prosentase $4 \%$ dari jumlah mol dari Zinc (Zn).

Deposisi lapisan tipis $\mathrm{ZnO}: \mathrm{Ag}$ di atas substrat alumunium foil menggunakan teknik thermal spray coating. Sebelum proses deposisi, substrat alumunium foil dibersihkan terlebih dahulu dengan dicuci dengan aseton, kemudian dicuci dengan metanol untuk menghilangkan pengotor organik seperti lemak dan minyak. Setelah itu substrat dicuci dengan Aqua Bides dan dikeringkan. Substrat alumunium foil yang telah kering diletakkan diatas hotplate pada temperatur $250{ }^{\circ} \mathrm{C}$ diatas selama 15 menit. Subtrat yang sudah dipanaskan dispray coating dengan larutan $\mathrm{ZnO}: \mathrm{Ag}$, kemudian dilakukan proses deposisi pada temperatur $250{ }^{\circ} \mathrm{C}$ selama 1 jam diatas hotplate. Proses pelapisan $\mathrm{ZnO}: \mathrm{Ag}$ dilakukan berulang dengan variasi suhu deposisi $300{ }^{\circ} \mathrm{C}$, $350{ }^{\circ} \mathrm{C}$ dan $400{ }^{\circ} \mathrm{C}$. Setelah dideposisi lapisan $\mathrm{ZnO}: \mathrm{Ag}$ dilanjutkan dipanaskan dengan suhu $500^{\circ} \mathrm{C}$ selama 1 jam menggunakan furnace.

Hasil pengujian lapisan $\mathrm{ZnO}: \mathrm{Ag}$ pada substrat alumunium foil dengan Scanning Electron Microscope (SEM) menghasilkan morfologi permukaan $\mathrm{ZnO}: \mathrm{Ag}$ di atas substrat alumunium foil didapatkan dengan Scanning Electron Microscope (SEM). Data yang diperoleh digunakan untuk mengetahui bentuk permukaan dan tingkat kekasaran permukaan serta luas permukaan $\mathrm{ZnO}: \mathrm{Ag}$.

Proses pengujian aktivitas fotokatalitik lapisan tipis $\mathrm{ZnO}: \mathrm{Ag}$ dengan substrat alumunium foil dilakukan dengan metode sebagai berikut: menyiapkan wadah yang terbuat dari kaca berukuran $30 \mathrm{~cm}$ x $30 \mathrm{~cm}$ x 30 $\mathrm{cm}$ yang telah dilapisi alumunium foil yang telah terlapisi $\mathrm{ZnO}$ :Ag kemudian diisi air yang telah tercemar zat warna batik methylene blue dengan konsentrasi 10 ppm sebanyak 200 mililiter. Kemudian wadah diberi paparan sinar uvdalam rentang waktu 4 jam. Setelah didapatkan hasilnya, sampel air zat warna batik diuji dengan spektrofotometer UV-Vis untuk mengetahui nilai absorbansinya. Jika air methylene blue terdegradasi maka nilai absorbansinya akan berkurang dari sampel awal.

\section{HASIL DAN PEMBAHASAN}

Lapisan tipis $\mathrm{ZnO}$ doping $\mathrm{Ag}$ dengan variasi suhu deposisi $250^{\circ} \mathrm{C}, 300^{\circ} \mathrm{C}, 350^{\circ} \mathrm{C}$, $400^{\circ} \mathrm{C}$ telah berhasil dideposisikan di atas substrat alumunium foil berukuran $30 \mathrm{~cm} \mathrm{x}$ $30 \mathrm{~cm} \times 0,1 \mathrm{~cm}$ menggunakan teknik thermal spray coating selama 1 jam dan disintering dengan suhu $500{ }^{\circ} \mathrm{C}$. Kemudian Lapisan $\mathrm{ZnO}: \mathrm{Ag}$ pada substrat alumunium foil dikarakterisasi menggunakan uji Scanning Electron Microscopy (SEM) untuk mengetahui morfologi lapisan $\mathrm{ZnO}: \mathrm{Ag}$ diatas substrat alumunium foil dengan suhu annealing yang berbeda, serta digunakan alat uji UV-Vis yang digunakan untuk mengetahui nilai absorbansi zat warna batik 
methylene blue setelah diberikan perlakuan irradiasi terhadap lapisan $\mathrm{ZnO}: \mathrm{Ag}$ pada substrat alumunium foil dengan bantuan sinar UV sebagai sumber irradiasi.

\section{Morfologi ZnO:Ag pada substrat alumunium foil}

Didapatkan morfologi $\mathrm{ZnO}$ :Ag 4\% pada substrat alumunium foil dengan variasi suhu deposisi $250{ }^{\circ} \mathrm{C}, 300{ }^{\circ} \mathrm{C}, 350{ }^{\circ} \mathrm{C}$ dan $400{ }^{\circ} \mathrm{C}$ setelah disintering adalah berbentuk ganglia dengan menempelnya bulir-bulir. Hal ini sesuai dengan hasil penelitian Anggita yang telah berhasil mendeposisikan lapisan $\mathrm{ZnO} / \mathrm{Ag} 4 \%$ pada substrat kaca membentuk struktur ganglia dengan bulir-bulir pada

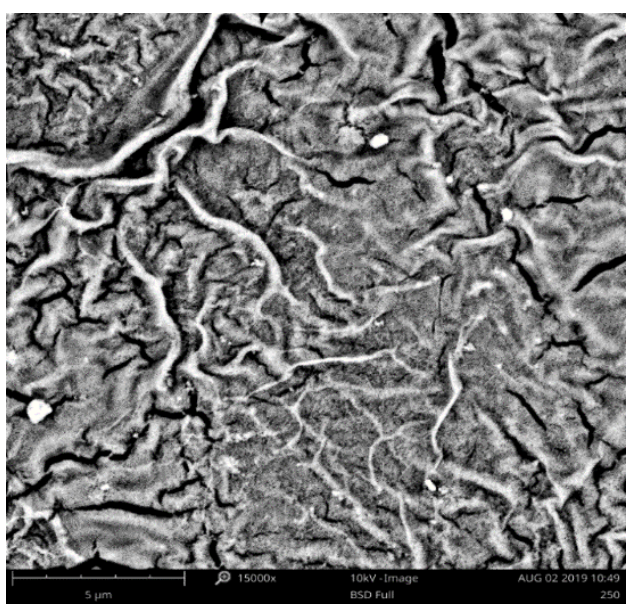

(a)

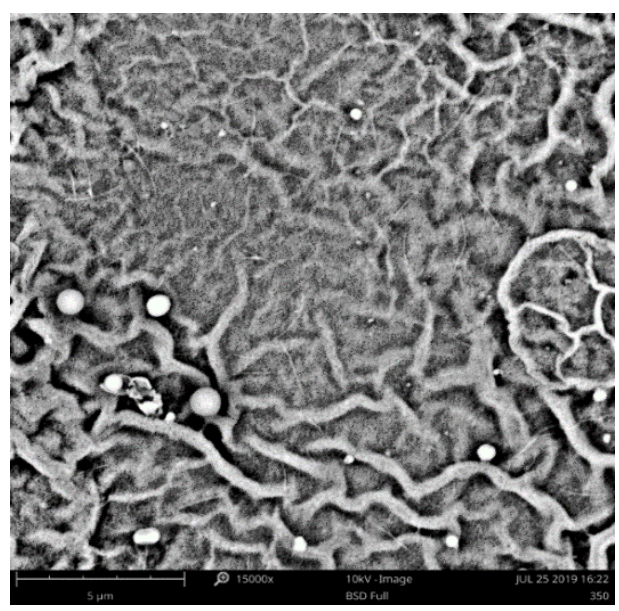

(c) permukaannya [14]. Diindikasikan ganglia adalah $\mathrm{ZnO}$ dan bulir-bulir sebagai Ag. Adanya struktur ganglia menambah tingkat kekasaran permukaan. Indikasi bahwa stuktur ganglia adalah $\mathrm{ZnO}$ berdasarkan hasil morfologi pada penelitian sebelumnya bahwa film $\mathrm{ZnO}$ yang dideposisikan di atas substrat kaca memiliki struktur seperti ganglia [15][16]. Sedangkan morfologi bulir-bulir yang diindikasikan sebagai bulir Ag berdasarkan hasil morfologi pada penelitian yang telah dilakukan oleh Saravanan menunjukkan bahwa nanopartikel Ag berbentuk bulir-bulir yang saling menempel pada permukaan nanorods [1].

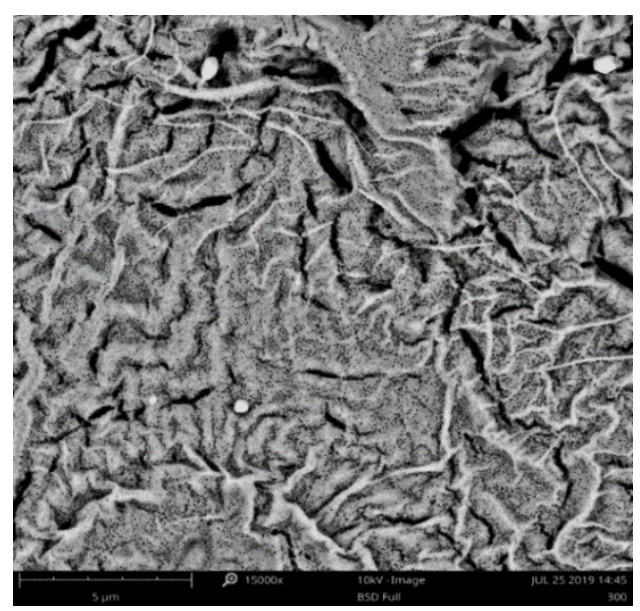

(b)

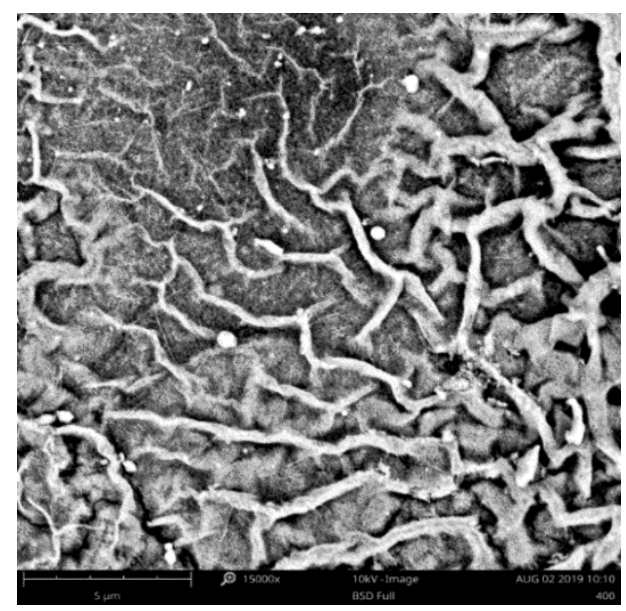

(d)

Gambar 1. Citra SEM lapisan $\mathrm{ZnO} / \mathrm{Ag} 4 \%$ dengan suhu deposisi (a) $250{ }^{\circ} \mathrm{C}$, (b) $300{ }^{\circ} \mathrm{C}$, (c) $350{ }^{\circ} \mathrm{C}$, (d) 400 ${ }^{\circ} \mathrm{C}$ setelah sintering 
Terlihat pada Gambar 1 pada suhu rendah (a) $250{ }^{\circ} \mathrm{C}$ pertumbuhan struktur ganglia lebih dominan terbentuk dibandingkan pertumbuhan bulir. Semakin bertambahnya suhu anil pertumbuhan bulir semakin meningkat. Hal ini ditunjukkan pada Gambar 1 (c) dan (d) semakin meningkatnya suhu anil menunjukkan bahwa pertumbuhan Ag semakin meningkat. Semakin besar ukuran bulir Ag maka akan semakin besar pula luas permukaannya. Semakin besar ukuran partikel akan menambah tingkat kekasaran dari permukaan sehingga meningkatkan luas permukaan [17]. Luas permukaan yang meningkat dapat dikaitkan dengan aktivitas fotokatalis, dengan permukaan yang luas mengakibatkan semakin banyak kekosongan oksigen sehingga meningkatkan difusi antara molekul organik ataupun anorganik dengan katalis.

Terlihat pada Gambar 1 (a) dan (b) banyak terdapat cacat berupa crack yang memanjang. Hal ini dikarenakan pada substrat aluminium foil memiliki permukaan yang tidak sempurna. Hal ini dikarenakan adanya interaksi antara substrat dan metal oxide mengakibatkan struktur yang terbentuk mempengaruhi aktivitas fotokatalitik. keberadaan banyak cacat dalam struktur film yang tumbuh di permukaan yang tidak sempurna dari aluminium foil mendukung pengembangan struktur ganglia yang lebih besar. Secara kontroversial, ketika struktur film ganglia lebih padat dengan kristalinitas yang lebih baik dan jumlah titik cacat yang lebih besar, maka laju pembawa muatan fotogenerasi rekombinasi akan berkurang dan film tersebut akan lebih berpartisipasi efektif dalam proses degradasi [16].

Permukaan $\mathrm{ZnO}$ :Ag yang terbentuk di atas substrat aluminium foil sangat berpengaruh terhadap aktivitas fotokatalitiknya, dikarenakan reaksi dari permukaan ganglia yang terbentuk pada $\mathrm{ZnO}: \mathrm{Ag}$. Di sisi lain adanya interaksi antara substrat yang digunakan yaitu aluminium foil dengan metal oxide yakni $\mathrm{ZnO}$ mengakibatkan perubahan yang signifikan dari performa fotokatalitiknya [16].

Citra 3D lapisan $\mathrm{ZnO}: \mathrm{Ag}$ pada substrat alumunium foil pada Gambar 2 menunjukkan pola morfologi yang kasar. Dari seluruh permukaan $\mathrm{ZnO}: \mathrm{Ag}$ pada substrat alumunium foil dengan variasi suhu deposisi didapatkan luas permukaan ratarata dan tingkat kekasaran permukaan ratarata.

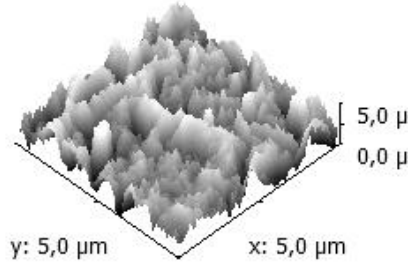

(a)

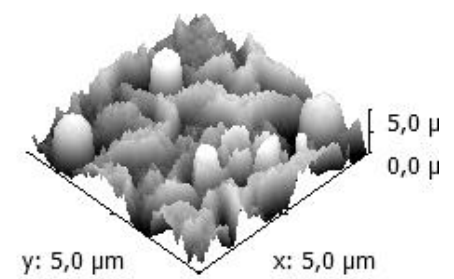

(c)

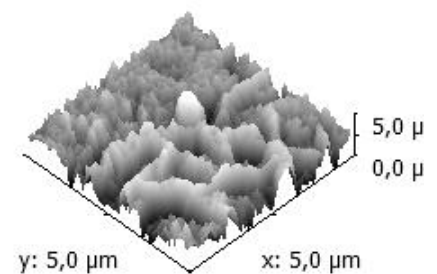

(b)

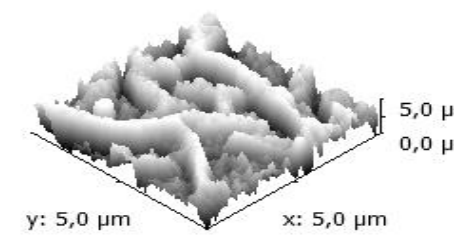

(d)

Gambar 2. Tampilan tiga dimensi permukaan lapisan $\mathrm{ZnO} / \mathrm{Ag}$ pada substrat alumunium foil dengan suhu annealing (a) $250{ }^{\circ} \mathrm{C}$; (b) $300{ }^{\circ} \mathrm{C}$; (c) $350{ }^{\circ} \mathrm{C}$; (d) $400{ }^{\circ} \mathrm{C}$ 
Tabel 1. Tabel luas permukaan rata-rata dan kekasaran permukaan rata-rata $\mathrm{ZnO}: \mathrm{Ag}$ pada substrat alumunium foil

\begin{tabular}{cccc}
\hline $\begin{array}{c}\text { Nama } \\
\text { Sample }\end{array}$ & $\begin{array}{c}\text { Surface Area } \\
\text { rata-rata }\end{array}$ & $\begin{array}{c}\mathrm{Ra} \\
\text { rata- } \\
\text { rata }\end{array}$ & $\begin{array}{c}\text { Rms } \\
\text { rata-rata }\end{array}$ \\
\hline $\begin{array}{c}\mathrm{ZnO}: \mathrm{Ag} \\
250^{\circ} \mathrm{C}\end{array}$ & 669,06 & 1,07 & 1,30 \\
$\mathrm{ZnO}: \mathrm{Ag}$ & 511,98 & 0,82 & 1,02 \\
$\begin{array}{c}300^{\circ} \mathrm{C} \\
\mathrm{ZnO}: \mathrm{Ag}\end{array}$ & 627,77 & 1,05 & 1,26 \\
$\begin{array}{c}350^{\circ} \mathrm{C} \\
\mathrm{ZnO}: \mathrm{Ag}\end{array}$ & 633,72 & 1,12 & 1,34 \\
$400^{\circ} \mathrm{C}$ & & & \\
\hline
\end{tabular}

Tabel 1 menunjukkan luas permukaan dan tingkat kekasaran menurun saat suhudeposisinya meningkat dari $250{ }^{\circ} \mathrm{C}$ - 300 ${ }^{\circ} \mathrm{C}$, dan luas permukaan dan tingkat kekasaran kembali meningkat pada suhu 350 ${ }^{\circ} \mathrm{C}-400{ }^{\circ} \mathrm{C}$. Tingkat kekasaran terbesar yaitu terdapat pada lapisan $\mathrm{ZnO}: \mathrm{Ag}$ suhu $400{ }^{\circ} \mathrm{C}$. $\mathrm{ZnO} / \mathrm{Ag}$ pada suhu $350^{\circ} \mathrm{C}-400{ }^{\circ} \mathrm{C}$ mulai terbentuk dekomposisi termal dari $\mathrm{AgO}$ menjadi Ag, dimana ikatan Ag-O lebih lemah dibandingkan ikatan Ag-Ag. Sedangkan pada temperatur rendah di bawah suhu $350{ }^{\circ} \mathrm{C}$ akan terbentuk $\mathrm{AgO}$ yang memiliki energi permukaan yang lebih besar, dimana kepadatan dari $\mathrm{ZnO}$ akan mengurangi luas permukaan dari fotokatalis. Dimana hal tersebut sangat berarti bagi permukaan adsorpsi dari pendegradasi [18]. Oleh karena itu luas permukaan $\mathrm{ZnO} / \mathrm{Ag}$ pada suhu deposisi di bawah $350{ }^{\circ} \mathrm{C}$ memiliki luas permukaan rendah dan permukaan menjadi meningkat saat suhu deposisi di atas $350^{\circ} \mathrm{C}$.

Luas permukaan ini juga dipengaruhi oleh perlakuan substrat sebelum dicoating dengan pembersihan dan pemanasan, hal ini dapat mengaktifkan permukaan substrat dengan meningkatkan energi permukaan bebas dan juga menawarkan manfaat dari peningkatan luas permukaan untuk ikatan partikel disemprot. Panas yang ditransfer ke partikel, sehingga partikel menyusut, mengeras dan menyatu dengan bahan substrat yang kasar karena adanya adhesi lapisan. Pemanasan pada saat proses spray membantu proses difusi partikel ke dalam substrat dan dapat meningkatkan ikatan yang terjadi antar partikel sehingga porositas hampir tidak ada [19]. Oleh karena itu, lapisan $\mathrm{ZnO}: \mathrm{Ag}$ saat suhu deposisinya meningkat memiliki luas permukaan yang besar.

\section{Kemampuan Fotokatalitik ZnO:Ag untuk Mendegradasi Methylene Blue}

Pada penelitian ini dilakukan pengujian fotokatalitik $\mathrm{ZnO}: \mathrm{Ag}$ pada substrat alumunium foil dengan melakukan degradasi terhadap zat warna methylene blue. Zat warna methylene blue yang digunakan dilarutkan dalam air dengan konsentrasi 10 ppm (part per million). Proses irradiasi menggunakan sumber cahaya lampu UV dengan panjang gelombang $380 \mathrm{~nm}$ dengan daya 20 Watt. Didapatkan dari pengujian ini adalah nilai absorbansi cahaya yang diserap oleh zat warna methylene blue akan sebanding dengan konsentrasi larutan di dalam kuvet. Semakin berkurang nilai absorbansinya maka konsentrasi larutan akan semakin berkurang pula.

Uji spektrofotometer UV-Vis untuk mengetahui besarnya absorbansi zat methylene blue dengan menggunakan panjang gelombang sinar UV dan sinar tampak. Setelah didapatkan nilai absorbansinya maka didapatkan persentase degradasi dari methylene blue setelah diberikan perlakuan dengan lapisan $\mathrm{ZnO}: \mathrm{Ag}$ pada substrat alumunium foil. Dari hasil persentase tersebut dapat ditentukan suhu annealing yang paling optimum dari $\mathrm{ZnO}: \mathrm{Ag}$ pada substrat alumunium foil untuk mendegradasi zat warna metyelene blue. 


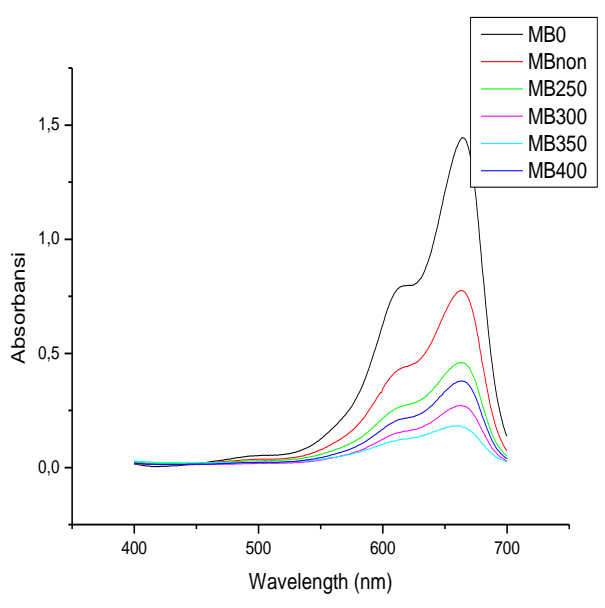

Gambar 3. Grafik Absorbansi zat methylene blue oleh $\mathrm{ZnO}: \mathrm{Ag}$ pada substrat alumunium foil

Gambar 3 merupakan grafik absorbansi zat Methylene Blue dengan berbagai jenis perlakuan. Dapat terlihat pada gambar bahwa grafik absorbansi Methylene Blue semakin menurun dengan adanya perlakuan irradiasi sinar UV. Nilai absorbansi sangat berkurang saat diberikan perlakuan dengan lapisan $\mathrm{ZnO}: \mathrm{Ag}$ dengan substrat alumunium foil. Tabel 2 merupakan hasil absorbansi zat warna methylene blue dan prosentase degradasi setelah irradiasi selama 4 jam.

Hasil yang diperoleh dari penelitiandari Tabel 2 menunjukkan bahwa lapisan $\mathrm{ZnO}: \mathrm{Ag}$ mampu mendegradasi zat warna methylene blue. Hal ini terlihat dari perubahan absorbansi dari zat warna methylene blue yang semakin berkurang. Apabila nilai absorbansinya berkurang maka zat methyelene blue yang terlarut dalam air juga akan semakin berkurang konsentrasinya. Maka semakin kecil konsentrasi methylene blue yang terlarut akan semakin banyak cahaya tampak yang ditranmitansikan. Dapat terlihat juga zat methylene blue $10 \mathrm{ppm}$ terdegradasi lebih baik dengan adanya lapisan $\mathrm{ZnO}$ :Ag pada substrat alumunium foil dibandingkan tanpa lapisan.
Tabel 2. Nilai Prosentase degradasi Methylene Blue (MB)

\begin{tabular}{ccc}
\hline Nama Sample & Absorbansi & \%degradasi \\
\hline MB awal & 1,445 & - \\
Mb non sampel & 0,776 & 46,30 \\
MB250 & 0,46 & 68,17 \\
MB300 & 0,272 & 81,18 \\
MB350 & 0,183 & 87,34 \\
MB400 & 0,379 & 73,77 \\
\hline
\end{tabular}

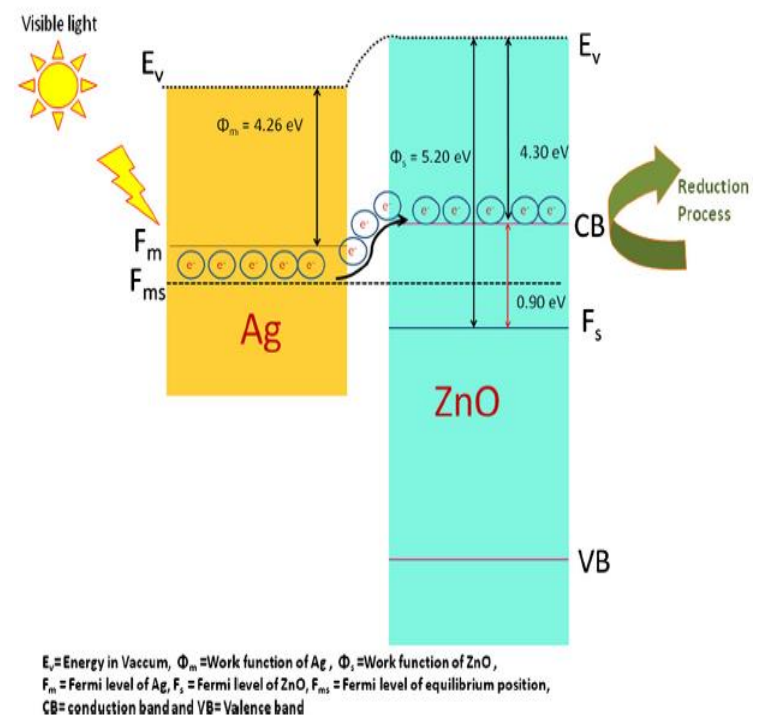

Gambar 4. Diagram skematik rekombinasi electronhole selama reaksi fotokatalitik pada $\mathrm{ZnO} / \mathrm{Ag}[1]$

Besarnya kemampuan degradasi zat warna methyelene blue tidak terlepas dari penambahan logam pada nanopartikel semikonduktor yang merupakan salah satu cara untuk meningkatkan efisiensi fotokatalitik. Manfaat tambahan doping logam transisi $\mathrm{Ag}$ adalah meningkatnya jumlah elektron yang terjebak agar menghambat proses rekombinasi electronhole selama radiasi. Penurunan proses rekombinasi akibat adanya tambahan doping dapat meningkatkan aktivitas fotokatalis [7]

Penambahan logam pada semikonduktor ini juga mempengaruhi proses interfacial charge transfer. Level Fermi Ag lebih tinggi dibandingkan $\mathrm{ZnO}$. Hal inilah yang akan memicu transfer 
elektron dari level Fermi Ag ke level Fermi $\mathrm{ZnO}$ hingga dua level tersebut seimbang dan membentuk level energi baru seperti pada Gambar 4 [1].

Ketika cahaya mampu mengeksitasi elektron pada $\mathrm{ZnO}: \mathrm{Ag}$ mengakibatkan elektron tereksitasi dari dari pita valensi ke pita konduksi. Hal ini mengakibatkan semakin banyak elektron yang berada pada pita konduksi, sedangkan pada pita valensi akan banyak terjadi kekosongan atau hole. Elektron yang tidak berekombinasi, maka elektron akan terjebak pada permukaan semikonduktor dan akan bereaksi dengan $\mathrm{O}_{2}$ membentuk membentuk superoksida $\left(\cdot \mathrm{O}_{2}{ }^{-}\right)$ yang berfungsi sebagai reduktor akan mengoksidasi larutan zat warna methylene blue. Sedangkan hole $\left(\mathrm{h}^{+}\right)$yang tidak berekombinasi akan terjebak pada permukaan semikonduktor dan bereaksi dengan $\mathrm{H}_{2} \mathrm{O}$ akan membentuk radikal hidroksil $(\cdot \mathrm{OH} \bullet)$ yang merupakan oksidator kuat untuk mereduksi zat warna methylene blue [1]. Reaksi-reaksi kimia tersebut akan berikatan dengan polutan-polutan disekitar material fotokatalis sehingga zat pewarna methylene blue tersebut akan terdegradasi. Radikal-radikal ini akan terbentuk terusmenerus selama film $\mathrm{ZnO}: \mathrm{Ag}$ disinari cahaya lampu UV.

Aktivitas fotokatalitik juga tidak terlepas dari peran morfologi permukaan $\mathrm{ZnO}: \mathrm{Ag}$ yang mempengaruhi luas permukaan dan tingkat kekasaran terhadap kemampuan dalam mendegradasi polutan. Seperti yang ditunjukkan pada tabel 1 bahwa $\mathrm{ZnO}$ :Ag pada suhu deposisi $300^{\circ} \mathrm{C}$ dan 350 ${ }^{\circ} \mathrm{C}$ memiliki luas area yang kecil dengan tingkat kekasaran (rms) yang kecil pula, sehingga memiliki kemampuan fotokatalitik yang lebih baik dibandingkan suhu yang lain. Hal ini disebabkan karena modifikasi perak pada suhu rendah di bawah $350{ }^{\circ} \mathrm{C}$ efektif untuk aktifitas fotokatalitik. Hal ini disebabkan karena kehadiran perak pada suhu tinggi di atas $350{ }^{\circ} \mathrm{C}$ mendorong adanya densifikasi dan pertumbuhan $\mathrm{ZnO}$ dengan membentuk kumpulan perak $(\mathrm{Ag})$ dalam matriks ZnO. Hal tersebut menyebabkan pengurangan permukaan aktif fotokatalis untuk adsorpsi degradan dan penyerapan cahaya [18]. Sehingga pada suhu deposisi di atas $350{ }^{\circ} \mathrm{C}$ memiliki efisiensi fotokatalitik yang lebih rendah dibandingkan pada suhu suhu deposisi 300 ${ }^{\circ} \mathrm{C}$ dan $350 \quad{ }^{\circ} \mathrm{C}$ karena pengurangan permukaan aktif fotokatalis yangdapat menghambat aktifitas fotokatalitiknya.

\section{KESIMPULAN}

Morfologi permukaan dari $\mathrm{ZnO}: \mathrm{Ag}$ dengan substrat alumunium foil dengan suhu annealing $250{ }^{\circ} \mathrm{C}, 300{ }^{\circ} \mathrm{C}, 350{ }^{\circ} \mathrm{C}$, dan $400{ }^{\circ} \mathrm{C}$ adalah bentuk ganglia dengan indikasi sebagai $\mathrm{ZnO}$ dan bulir $\mathrm{Ag}$ yang menempel pada $\mathrm{ZnO}$. Didapatkan luas permukaan dan tingkat kekasaran $\mathrm{ZnO}: \mathrm{Ag}$ menurun dengan adanya peningkatan suhu dari $250{ }^{\circ} \mathrm{C}-300{ }^{\circ} \mathrm{C}$, dan kembali meningkat pada suhu $350{ }^{\circ} \mathrm{C}-400{ }^{\circ} \mathrm{C}$. Tingkat kekasaran terbesar yaitu terdapat pada lapisan $\mathrm{ZnO}: \mathrm{Ag}$ suhu $400^{\circ} \mathrm{C}$

Pengujian fotokatalitik lapisan $\mathrm{ZnO}: \mathrm{Ag}$ pada substrat alumunium foil dengan variasi suhu annealing telah diujicobakan pada zat warna batik methylene blue dengan irradiasi sinar UV selama 4 jam. Hasil penelitian menunjukkan bahwa prosentase degradasi terbesar ditunjukkan oleh lapisan $\mathrm{ZnO}: \mathrm{Ag}$ dengan suhu $350{ }^{\circ} \mathrm{C}$ sebesar $87,34 \%$. Hal ini disebabkan karena modifikasi perak pada suhu rendah efektif untuk aktifitas fotokatalitik.

\section{DAFTAR PUSTAKA}

[1] R. Saravanan et al., " $\mathrm{ZnO} / \mathrm{Ag}$ nanocomposite: An efficient catalyst for degradation studies of textile effluents under visible light," Mater. Sci. Eng. C, vol. 33, no. 4, pp. 2235 2244, 2013.

[2] S. Baruah, S. K. Pal, and J. Dutta, "Nanostructured Zinc Oxide for 
Water Treatment," Nanosci.

Technol., vol. 2, no. 2, pp. 90-102, 2012.

[3] A. Fujishima, T. N. Rao, and D. A. Tryk, "Titanium dioxide photocatalysis," J. Photochem. Photobiol. C Photochem. Rev., vol. 1, no. 1, pp. 1-21, 2000.

[4] P. Amornpitoksuk, S. Suwanboon, S. Sangkanu, A. Sukhoom, N. Muensit, and J. Baltrusaitis, "Synthesis, characterization, photocatalytic and antibacterial activities of Ag-doped $\mathrm{ZnO}$ powders modified with a diblock copolymer," Powder Technol., vol. 219, pp. 158-164, 2012.

[5] N. L. Tarwal and P. S. Patil, "Enhanced photoelectrochemical performance of $\mathrm{Ag}-\mathrm{ZnO}$ thin films synthesized by spray pyrolysis technique," Electrochim. Acta, vol. 56, no. 18, pp. 6510-6516, 2011.

[6] R. Chauhan, A. Kumar, R. P. Chaudhary, and T. Education, "Synthesis and characterization of silver doped $\mathrm{ZnO}$ nanoparticles," Arch. Appl. Sci. Res., vol. 2, no. 5, pp. 378-385, 2010.

[7] A. Zaleska, "Doped-TiO2: A Review," Recent Patents Eng., vol. 2, no. 3, pp. 157-164, 2008.

[8] Z. G. Jia, K. K. Peng, Y. H. Li, and R. S. Zhu, "Preparation and photocatalytic performance of porous $\mathrm{ZnO}$ microrods loaded with Ag," Trans. Nonferrous Met. Soc. China (English Ed., vol. 22, no. 4, pp. 873878, 2012.

[9] T. Ali, A. Ahmed, U. Alam, I. Uddin, P. Tripathi, and M. Muneer, "Enhanced photocatalytic and antibacterial activities of $\mathrm{Ag}$-doped TiO2 nanoparticles under visible light," Mater. Chem. Phys., vol. 212, pp. 325-335, 2018.

[10] S. R. Anggita, "No Title," in papers Seminar Nasional Quantum \#25, 2018.

[11] L. S. Chuah and H. I. Abdulgafour, "Preparation Of Aluminum FoilSupported ZnO Nanocoral Reef Films," pp. 42-45, 2013.

[12] F. Peng, H. Wang, H. Yu, and S. Chen, "Preparation of aluminum foilsupported nano-sized $\mathrm{ZnO}$ thin films and its photocatalytic degradation to phenol under visible light irradiation," Mater. Res. Bull., vol. 41, no. 11, pp. 2123-2129, 2006.

[13] M. Jabeen, M. T. Javed, M. W. Ashraf, S. Tayyaba, R. V Kumar, and D. Okara, "SYNTHESIS OF ZnO NANORODS ON ALUMINUM FOIL FOR ETHANOL SENSING AT LOW TEMPERATURE is high enough . High temperature is essential for creation of reaction mechanism . As the," vol. 12, no. 4, pp. 981-992, 2017.

[14] S. R. Anggita, "Preparation and Microstructure of Ag Doped on ZnO," J. Nat. Sci. Math Res., vol. 2, no. 2, pp. 148-152, 2016.

[15] M. Pusvitasari, "Deposisi Lapisan Tipis Zinc Oxide ( $\mathrm{ZnO})$ di Atas Substrat Kaca dengan Metode SolGel untuk Aplikasi Degadrasi Warna," Youngster Phys. J., vol. 1, no. 1, 2012.

[16] N. Kaneva, A. Bojinova, and Et.al, "Effect of the Substrate on the Photocatalytic Efficiency of $\mathrm{ZnO}$ 
Film for Malachite Green Degradation," J. Chem. Technol. Metall., vol. 49, no. 2, pp. 149-156, 2014.

[17] J. B. You, X. W. Zhang, Y. M. Fan, Z. G. Yin, P. F. Cai, and N. F. Chen, "Effects of the morphology of $\mathrm{ZnO} / \mathrm{Ag}$ interface on the surfaceplasmon-enhanced emission of $\mathrm{ZnO}$ films," J. Phys. D. Appl. Phys., vol. 41, no. 20, p. 205101, 2008.
[18] R. Georgekutty, M. K. Seery, and S. C. Pillai, "A highly efficient Ag-ZnO photocatalyst: Synthesis, properties, and mechanism," J. Phys. Chem. C, vol. 112, no. 35, pp. 13563-13570, 2008 .

[19] S. Metco, "An Introduction to Thermal Spray," no. 5, pp. 1-24, 2012. 